\title{
PERAN EKONOMI KREATIF DALAM MENGATASI PROBLEMATIKA ANGKATAN KERJA
}

\author{
Andi Kaimuddin \\ Program Studi Pendidikan Luar Sekolah, Jurusan Ilmu Pendidikan, \\ Fakultas Keguruan dan Ilmu Pendidikan, Universitas Muhammadiyah Palu \\ andi.kaie@gmail.com
}

\begin{abstract}
Ekonomi kreatif merupakan kemampuan kreatif dan inovatif untuk berkreasi pada setiap karya kreatif yang diciptakan oleh angkatan kerja dalam menjawab problematika. Diperlukan ide kreatif sehingga dapat membuka lapangan pekerjaan yang dapat meringankan beban pemerintah untuk mengurangi tingginya angka pengangguran di angkatan kerja produktif. Terdapat sejumlah kelompok usaha ekonomi kreatif yang saat dikembangkan di Indonesia. Semakin banyaknya angkatan kerja yang terlibat di aktifitas ekonomi kreatif, semakin tinggi produktivitas yang dihasilkan sehingga akan berpengaruh pada pertimbuhan ekonomi nasional. Diperlukan keterlibatan pemerintah melalui regulasi dan stake holder dalam kegiatan pengembangan ekonomi kreatif.
\end{abstract}

Kata kunci: ekonomi kreatif, angkatan kerja, regulasi.

\section{PENDAHULUAN}

Sebagaimana diketahui, Indonesia termasuk sebagai salahsatu negara yang mempunyai jumlah penduduk terbesar dunia diperingkat ke empat setelah China, India, dan Amerika. dengan pertumbuhan ekonomi terbesar kesepuluh berdasarkan paritas daya beli,. Saat ini Indonesia telah berhasil meminimalisir angka kemiskinan lebih dari separuhnya sejak tahun 1999. Adapun prosentasenya menjadi 9,8\% pada tahun 2018.

Sebagai negara terbesar dalam jumlah penduduk di Asia Tenggara, Indonesia mempunyai lebih dari 300 suku dan berbagai macam bahasa daerah. Seiring hal tersebut, tingkat pertumbuhan ekonomi yang cenderung baik sejak terjadinya badai krisis moneter di penghujung abad 20. Indonesia juga sebagai pelaku ekonomi dan UMKM terbesar di Asia Tenggara, Sumber Daya Alam yang melimpah dengan 2/3 wilayahnya adalah lautan.

Rencana ekonomi Indonesia telah digariskan dalam rencana pembangunan jangka panjang untuk tahun 2005-2025 yang disusun secara bertahap dalam periode lima tahun. Rencana ini mempunyai skala prioritas pembangunan yang berbeda tiap tahapannya. Tahun ini merupakan tahap ketiga, yang ditikberatkan pada pembangunan infrastruktur dan peningkatan program bantuan pada bidang pendidikan dan jaminan sosial kesehatan. Dari sekitar 260 juta penduduk Indonesia, kurang lebih 25,9 juta orang yang hidup di bawah ambang batas kemiskinan. Data bulan Maret tahun 2017, hampir 21\% dari total jumlah penduduk berada di batas definisi kemiskinan karena pendapatan mereka berada hampir menyentuh ambang batas garis kemiskinan.

Dalam segi luas wilayah, Indonesia merupakan negara paling luas di Asia Tenggara. Indonesia memiliki lebih dari 16.000 pulau, telah berhasil memacu pertumbuhan ekonomi yang baik sejak krisis moneter yang melanda negara-negara Asia di akhir abad 20. Dukungan investasi yang cukup baik, inflasi 
yang condong mengarah pada kestabilan dan tenaga kerja yang terdistribusi dengan baik sesuai dengan keterampilannya, maka pada tahun 2019 pertumbuhan ekonomi Indonesia diproyeksikan akan berada diatas $5 \%$.

Sebagai negara yang mempunyai kekayaan sumber daya alam terlebih potensi sumber daya kelautan yang cukup besar, tingkat pertumbuhan ekonomi masih jauh dari standar. Salah satu penyebab utamanya adalah tingkat pertambahan penduduk dan angkatan kerja yang tidak berbanding lurus dengan pembukaan lapangan pekerjaan. Masalah pemenuhan kebutuhan angkatan kerja masih belum maksimal, ini dikarenakan banyaknya masalah-masalah yang timbul dan mempunyai keterikatan masalah antara satu dengan lainnya.

\section{TINJAUAN PUSTAKA}

Problem utama angkatan kerja di beberapa negara termasuk Indonesia disebabkan karena tingkat pengangguran di angkatan kerja yang tergolong tinggi. Semua negara mempunyai problem pemenuhan kebutuhan angkatan kerja. Namun ini akan menjadi masalah serta akan menimbulkan kerawanan sosial jika prosentasenya tinggi.

Tingkat pengangguran yang tinggi di angkatan kerja menandakan pertumbuhan ekonomi yang rendah. Mengapa demikian? Ini disebabkan karena kebutuhan angkatan kerja terhadap pekerjaan tidak mampu menampung kebutuhan tersebut. Salah satu penyebab utama minimnya jumlah lapangan pekerjaan adalah tingkat pertumbuhan ekonomi yang cenderung rendah.

Menurut Badan Pusat Statistik :

1. Angkatan kerja : adalah penduduk usia kerja mulai usia 15 tahun yang sudah bisa bekerja,

2. Bukan angkatan kerja ; adalah penduduk usia kerja (15 tahun dan lebih), masih sekolah, mengurus rumah tangga atau melaksanakan kegiatan lainnya.

3. Bekerja ; adalah kegiatan yang dilakukan oleh seseorang dengan maksud memperoleh atau membantu memperoleh penghasilan, minimal 1 jam (tidak terputus) perminggu. Kegiatan tersebut termasuk pola kegiatan pekerja tak dibayar yang membantu dalam suatu usaha/kegiatan ekonomi.

4. Punya pekerjaan tetapi sementara tidak bekerja adalah keadaan dari seseorang yang mempunyai pekerjaan tetapi selama seminggu yang lalu sementara tidak bekerja karena berbagai sebab, seperti: sakit, cuti, menunggu panenan, mogok dan sebagainya.

5. Penganggur terbuka ; tak punya pekerjaan, tidak mencari pekerjaan, sementara mencari pekerjaan, sementara mempersiapkan usaha, sudah punya pekerjaan tapi menanti mulainya bekerja.

Dalam rilis Badan Pusat Statistik (BPS) tahun 2018, menyebutkan bahwa terdapat kenaikan jumlah angkatan kerja dari tahun 2017 ke tahun 2018. Lebih lanjut dikatakannya, tingkat partisipasi angkatan kerja (TPAK) juga meningkat sebaesar 0,59\%. Begitu pun untuk penduduk yang bekerja.

Untuk lebih jelasnya bisa lihat pada table berikut : 
Tabel 1.

Kenaikan Jumlah Angkatan Kerja dan Penduduk Yang Bekerja

\begin{tabular}{lccc}
\hline Bulan / Tahun & $\begin{array}{c}\text { Angkatan Kerja } \\
\text { (Juta) }\end{array}$ & $\begin{array}{c}\text { Penduduk Yang Bekerja } \\
\text { (Juta) }\end{array}$ & $\begin{array}{c}\text { Partisipasi Angkatan } \\
\text { Kerja (\%) }\end{array}$ \\
\hline Agustus 2017 & 131,01 & 124,01 & \\
Agustus 2018 & 33,96 & 126,91 & $+0,59 \%$ \\
\hline Kenaikan & 2,95 & 2,9 & $+0,59 \%$ \\
\hline
\end{tabular}

Dalam rilis selanjutnya, Badan Pusat Statistik (2018) menyebutkan bahwa ketersediaan lapangan pekerjaan mengalami peningkatan persentase, khususnya bidang Penyediaan Akomodasi dan Makan Minum sebesar 0,47\%, Industri Pengolahan sebesar 0,21\%, dan Transportasi sebesar 0,17\%. Beberapa bidang lainnya mengalami penuruunan prosentase, utamanya pada Pertanian dengan prosentase $0,89 \%$, Jasa Lainnya sebesar 0,11\% dan Jasa Pendidikan sebesar 0,05\%.

\section{Tingginya pertumbuhan angkatan kerja}

Angkatan kerja merupakan bagian yang sangat signifikan dari jumlah penduduk. Secara teori, dampak dari semakin tinggi jumlah penduduk suatu negara akan berdampak kepada tingginya jumlah angkatan kerja beserta penyediaan fasilitas lapangan kerja.

Pertambahan penduduk yang tinggi tidak sebanding dengan pemenuhan kebutuhan angkatan kerja, ini menjadi kemudian suatu problem krusial. Selain tingkat kebutuhan ekonomi dan kebutuhan pendidikan yang masih belum memadai, pengambil kebijakan masih mengutamakan beberapa skenario dalam membuka lapangan kerja, khususnya dibidang pertanian. Sementara sector lainnya yang juga diharapkan dapat menampung tenaga kerja sangat membutuhkan sumber daya yang memiliki tingkat keterampilan dan merupakan lulusan dari pendidikan yang lebih tinggi.

\section{Rendahnya tingkat pendidikan dan keterampilan angkatan kerja}

Melihat beberapa permasalahan diatas, tidak banyak yang bisa dilakukan jika angkatan kerja di Indonesia hanya bermodalkan ijazah Sekolah Dasar. Secara logika, seseorang yang berpendidikan lulusan Sekolah Dasar hanya mempunyai pendidikan dan keterampilan terbatas terbatas. Berbanding terbalik dengan angkatan kerja yang merupakan lulusan Sekolah Menengah Umum/Kejuruan ataupun Perguruan Tinggi yang tentunya mempunyai mempunyai banyak keterampilan serta dapat mengerjakan lebih banyak pekerjaan berdasarkan ilmu yang diperolehnya di sekolah atau perguruan tinggi. Angkatan kerja yang lebih terampil diharapkan dapat berpartisipasi pada sector wirausaha, bahkan dapat menciptakan lapangan pekerjaan sendiri, terlebih lagi yang bisa mempekerjakan orang lain. 
Saat ini, paradigma penduduk Indonesia terhadap lapangan pekerjaan khususnya angkatan kerja masih berharap pada sektor yang relatif sederhana.. Maka, tidak aneh jika angkatan kerja Indonesia hampir selalu mengharapkan sektor pertanian untuk menjadi lapangan kerja mereka.

\section{Tidak meratanya penyebaran angkatan kerja}

Wilayah Indonesia yang 2/3 wilayahnya adalah lautan (maritim) dan memiliki dari lebih 16.000 pulau, penyebaran angkatan kerja Indonesia tidak merata dan terfokus di daerah tertentu saja (Jawa). Sangat terlihat perbedaan pertumbuhan ekonomi antara daerah khususnya yang berdekatan dengan pusat pemerintahan dengan daerah yang berjauhan dengan pusat pemerintahan. Pesona daya tarik ibu kota negara sebagai pusat pemerintahan menjadi alasan urbanisasi yang tidak terkendali. Bahkan, hampir $60 \%$ dari total penduduk Indonesia dan pengelolaan keuangan berada di pusat pemerintahan. Hal ini membuat banyak daerah yang jauh dari pusat pemerintahan kesulitan untuk melaksanakan pembangunan infrastruktur serta pengembangan sumber daya manusia akibat tidak memadai dan mencukupinya sumber daya manusia.

\section{Pengembangan Ekonomi Kreatif}

Istilah ekonomi kreatif sebagai bagian dari bidang kewirausahaan belumlah menjadi wacana menarik untuk didiskusikan. Meski wacana ini telah menjadi pointer dari kebijakan kementerian pada paruh kedua pemerintahan Presiden SBY dengan membentuk Kementerian Pariwisata dan Ekonomi Kreatif. Secara definisi umum, ekonomi kreatif merupakan sebuah tindakan di era ekonomi baru yang dinamis dengan mengoptimalkan nilai-nilai informasi dan kreativitas serta mengandalkan kreasi, ide, dan keterampilan dari sumber daya manusia sebagai faktor utama.

Konsep ini biasanya akan berkembang seiring dengan perkembangan teknologi terbarukan dimana keberadaan industri ekonomi kreatif yang menjadi aplikasi tindakan. Saat ini dunia dihadapi dengan konsep ekonomi informasi yang mana informasi menjadi hal yang utama dalam pengembangan ekonomi dalam membuka lapangan pekerjaan baru.

John Howkins (2001) adalah seorang ilmuwan yang pertama kali mempopulerkan istilah ekonomi kreatif serta melihat dan merasakan munculnya dinamika ekonomi baru berbasis pada kreativitas dan produktivitas pada pertengahan tahun 1997.

Peluang pengembangan industri ekonomi kreatif dibeberapa tahun terakhir ini banyak dipengaruhi oleh :

\section{a. Bonus Demografi}

Diperkirakan hingga tahun 2030, usia angkatan kerja akan melebihi 60\% dari total jumlah penduduk. Sekitar $30 \%$ di antaranya adalah penduduk muda dengan 16-30 tahun.

\section{b. Teknologi Informasi dan Komunikasi sebagai Gaya Hidup}

Lebih dari $80 \%$ penduduk Indonesia telah menggunakan perangkat teknologi informasi dan komunikasi

\section{c. Produk Kreatif sebagai Trend Baru}

Permintaan di pasar global terutama produk berbasis media akan meningkat sebagai trend baru yang berbasis ICT (content industry). 
d. Pertumbukan Kelas Menengah yang Meningkat

Diperkirakan pada tahun 2030, hampir 140 juta penduduk Indonesia memiliki penghasilan bersih (net income) di atas Rp.50.000.000 sebagai konsumen ekonomi kreatif.

\section{e. Kekayaan Alam dan Budaya sebagai Potensi Baru}

Indonesia memiliki kekayaan dan keindahan alam yang belum tersentuh yang selama ini dianggap sebagai penghias alam saja. Dirproyeksi kekayaan alam tersebut akan dapat digunakan sebagai bahan baku industri ekonomi kreatif.

Beberapa hal tersebut diatas bahkan saat ini telah berlangsung dan menjadi trend dalam beberapa sendi kehidupan penduduk Indonesia.

\section{HASIL DAN PEMBAHASAN}

Inpres No. 6 Tahun 2009 menyebutkan ekonomi kreatif adalah kegiatan ekonomi berdasarkan pada kreativitas, keterampilan, dan bakat individu untuk menciptakan daya kreasi dan daya cipta individu yang bernilai ekonomis dan berpengaruh pada kesejahteraan masyarakat.

Ruang lingkup ekonomi kreatif di Indonesia agak berbeda dengan di beberapa negara lainnya, dimana bidang penelitian dan pengembangan sebagai bagian dari ekonomi kreatif. Di beberapa negara Eropa, bidang penelitian dan pengembangan tidak dimasukkan sebagai ruang lingkup industri ekonomi kreatif. Berdasarkan pendapat Dr. Hamdan selaku asisten deputi Bidang Koordinasi Ekonomi Kreatif, bidang-bidang yang termasuk dalam ruang lingkup ekonomi kreatif di Indonesia dan peluang investasi adalah sebagaimana table berikut :

Tabel 2.

Bidang dan Ruang Lingkup Ekonomi Kreatif

Bidang

1. Arsitektur

2. Desain Interior

3. Desain Komunikasi Visual

4. Film, Animasi dan Video

5. Fotografi

6. Kriya
Ruang Lingkup Kegiatan

Jasa konsultan perancangan bangunan perumahan, karya yang memiliki nilai artistik dan budaya yang menjadi icon suatu wilayah.

Jasa konsultan dan pendidikan desain

Jasa konsultan dan desain komunikasi secara visual

Usaha reproduksi media rekaman; studio produksi, pasca produksi film, video dan program televisi, pembuatan film pendek, penayangan film, pembuatan merchandise.

Jasa dan pendidikan fotografi

Usaha kerajinan berbahan dasar kain, kulit, 
Anyaman dan pengolahan kayu, kertas, kaca, logam, mebel dan perhiasan

7. Kuliner

8. Musik

9. Fashion

10. Aplikasi dan Game Developer

11. Penerbitan

12. Periklanan

13. Radio dan Televisi

14. Seni dan Pertunjukan

15. Seni Rupa
Rumah makan dan minuman

Pembuatan alat musik, jasa pendidikan musik

pertunjukan, studio rekaman, penerbitan musik.

Usaha pembuatan pakaian, barang dari kulit, alas kaki.

Usaha pembuatan aplikasi dan game, usaha merchandise, usaha publisher aplikasi dan game, usaha pembuatan permainan anak-anak.

Usaha percetakan, usaha penerbitan buku/majalah.

Jasa pembuatan iklan.

Usaha broadcast radio dan televisi swasta.

Kegiatan pentas tari, pendidikan seni.

Gedung pameran kesenian, jasa pendidikan dan desain seni rupa.

\section{Kontribusi Ekonomi Kreatif Terhadap Perekonomian Nasional}

Dalam berbagai referensi disebutkan, ekonomi kreatif memberikan sumbangsih terhadap pertumbuhan ekonomi nasional. Sumbangsih tersebut dapat dilihat pada table berikut :

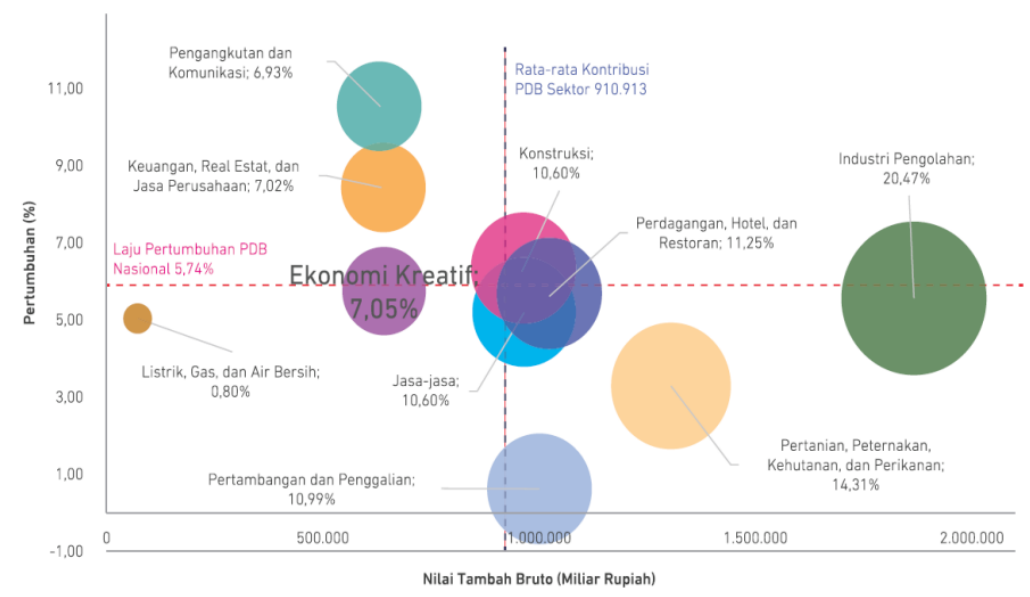

Gambar 1. Konstribusi Ekonomi Kreatif Terhadap Perekonomian Nasional

(Sumber : Deputi Bidang Koordinasi Ekonomi Kreatif, Kewirausahaan, Daya Saing Koperasi dan UKM)

\section{Pembangunan Ekonomi Kreatif}

Berdasarkan agenda nasional yang diwujudkan dalam NAWACITA 2015-2019 Pemerintahan Jokowi-JK, secara spesifik yang menyebutkan membantu peningkatan produktivitas rakyat yang mampu bersaing di pasar global dan mampu menempatkan Negara Indonesia setara dengan Negara-negara di level 
Asia.

Adapun issu strategisnya adalah "Mencapai pertumbuhan yang tinggi dan mengutamakan penumbuhan usaha pemula di ekonomi kreatif", dengan menggunakan cara ;

1. Memperluas pasar ekspor dan domestik.

2. Memberikan dan mengembangkan fasilitas ruang kreasi dan keratif serta jaringan.

3. Memberikan ruang fasilitas kepada rantai nilai ekonomi kreatif

4. Pengembangan bisnis start-up

Sementara itu pengembangan kebijakan yang tengah dirancang, antara lain :

1. Pembuatan regulasi bagi pengembangan ekonomi kreatif secara nasional.

2. Pengembangan alur pembiayaan bagi ekonomi kreatif secara khusus.

3. Perancangan kriteria dan indikator kota kreatif sebagai wilayah pembentukan ekosistem ekonomi kreatif sebagai basis pengembangan.

4. Dukungan dan fasilitasi wirausaha pemula (start-up) berbasis teknologi terbarukan.

\section{Pengembangan Sub Sektor Ekonomi Kreatif dan Dukungan Fasilitas Pemerintah}

Keseriusan pemerintah dalam mengatasi membludaknya angkatan kerja di Indonesia ditunjukkan lewat dibentuknya Badan Ekonomi Kreatif (BEKRAF). Pemerintah fokus mendukung perkembangan ekonomi kreatif ini untuk menjadi salah satu point pertumbuhan ekonomi Indonesia. Beberapa hal yang menjadi program BEKRAF adalah :

1. Inkubasi sub sektor ekonomi kreatif dan membuka skema perdagangan ke pasar internasional.

2. Pengembangan usaha bagi pemula yang pertumbuhannya belum maksimal.

3. Fasilitasi usaha kreatif pemula (start-up) berbasis teknologi terbarukan.

Pemerintah juga mengajak pihak swasta dalam hal ini stake holder dalam pengembangan sub sektor ekonomi kreatif dengan menberikan beberapa kemudahan kebijakan kepada stake holder seperti :

1. Bantuan Modal Untuk Pembiayaan Awal

Memfasilitasi bidang lingkup ekonomi kreatif melalui alur KUR, pendampingan melalui fasilitator ahli kepada bank pemodal sebagai penyalur KUR oleh pihak Kementerian terkait, BEKRAF, dan Otoritas Jasa Keuangan.

2. Sumber Daya Manusia

Dukungan bantuan pendidikan dan pelatihan untuk peningkatan sumber daya pelaku ekonomi/industri kreatif bidang produksi, manajemen keuangan, skema distribusi dan lainya serta memfasilitasi akreditasi/sertifikasi pelaku ekonomi/industri kreatif oleh pihak terkait yang telah diakreditasi dan ditunjuk oleh pemerintah.

3. Distribusi dan Pemasaran Produk

Memberi dukungan berupa regulasi dan fasilitas penyelenggaraan serta partisipasi dalam kegiatan pameran sebagai bentuk pengenalan dan promosi produk di dalam atau luar negeri, pengembangan pusat ekshibisi dan memfasilitasi roadmap pengembangan e-commerce oleh Kementerian Koordinator 
Perekonomian, BEKRAF, OJK dan Bank Indonesia.

\section{Strategi Pengembangan Ekonomi Kreatif di Tingkat Daerah}

Kementerian Koordinator Bidang Perekonomian Republik Indonesia menjelaskan bahwa terdapat jenis Kabupaten dan Kota Kreatif. Adapun yang dimaksud Kabupaten dan Kota Kreatif itu adalah kabupaten dan kota yang bisa mengidentifikasi, sanggup memanfaatkan, mengelola, serta melakukan rekayasa kreativitas dalam memanfaatkan ilmu pengetahuan dan teknologi untuk mengembangkan potensi daerah masing-masing menjadi keunggulan kompetitif dan mengangkat identitas potensi daerah dalam mendorong peningkatan kemakmuran dalam pencapaian pembangunan.

Untuk lebih jelasnya alur definisi Kabupaten dan Kota Kreatif dapat dilihat pada table berikut ini :

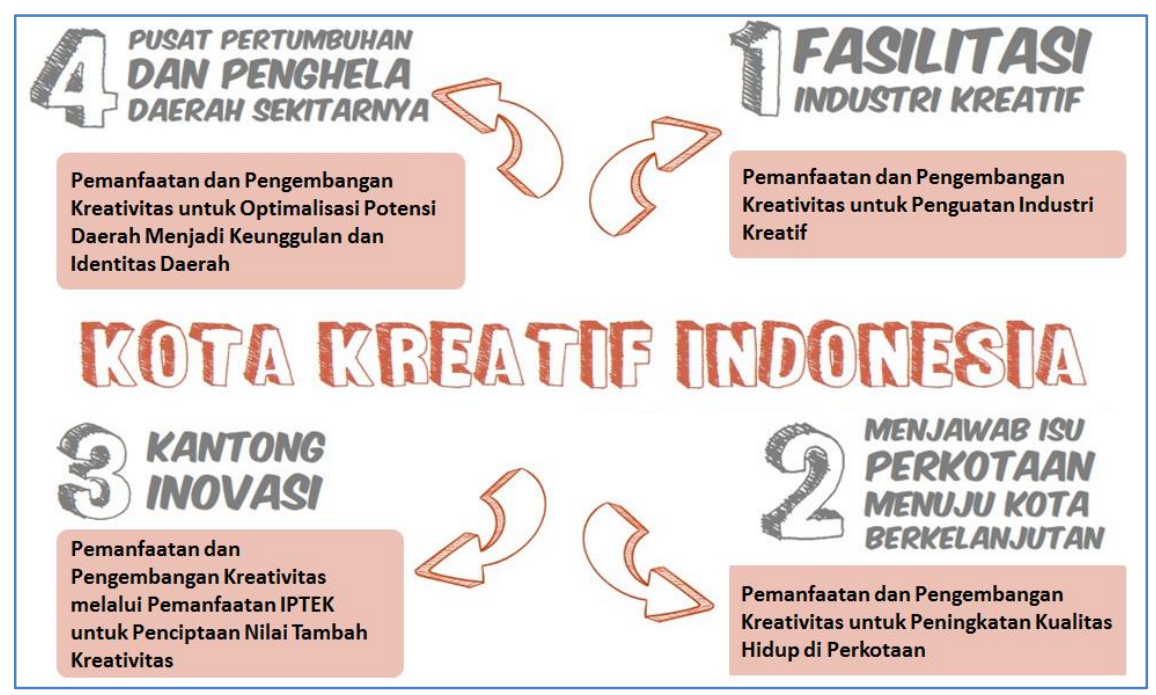

Gambar 2.

Kabupaten dan Kota Kreatif

(Sumber : Deputi Bidang Koordinasi Ekonomi Kreatif, Kewirausahaan, Daya Saing Koperasi dan UKM)

\section{KESIMPULAN}

Pengangguran umumnya disebabkan karena membludaknya pertambahan penduduk yang tidak sebanding dengan jumlah lapangan pekerjaan yang mampu menyerap angkatan kerja. Ini kemudian akan menjadi masalah social di masyarakat. Secara keseluruhan maka hasil dari studi awal pemetaan angkatan kerja di Indonesia adalah mengenali problematika yang terjadi pada angkatan kerja.

Ekonomi kreatif di Indonesia mulai mendapat pengakuan serta memiliki konstribusi yang sangat penting dalam pertumbuhan ekonomi daerah yang kemudian berdampak kepada daerah. Terobosan Pemerintah melalui program Indonesia Design Power oleh pemerintah yang didukung oleh regulasi yang tepat sangat diharapkan dapat meningkatkan kompetensi serta kemampuan kompetisi produk-produk kreatif angkatan kerja Indonesia di pasar domestik dan pasar Internasional.

Modal dasar yang dibutuhkan dalam menjawab tantangan tersebut adalah membuat terobosan dari pihak terkait dalam hal ini pemerintah dan stake holder dalam membuat program-program ekonomi kreatif yang tentunya didukung oleh regulasi. Regulasi ini harus memiliki kekuatan sosial yang fokus kepada 
jawaban atas kebutuhan angkatan kerja. Kerangka strategis pengembangan ekonomi kreatif Indonesia perlu mendapat apresiasi baik serta perlu didorong guna menjawab problem angkatan kerja. Upaya ini merupakan bagian dari mempertahankan keberlanjutan tingkat pertumbuhan dan pembangunan ekonomi serta pengembangan usaha di era persaingan global serta menjawab problematika angkatan kerja.

\section{DAFTAR PUSTAKA}

Kementerian Perdagangan Republik Indonesia, 2009, Studi industri kreatif Indonesia, Jakarta: Kementerian Perdagangan Republik Indonesia.

John Howkins, The Creative Economy: How People Make Money from Ideas, 2001, USA: Penguin Global. Hamdan, Kebijakan dan Strategi Pengembangan Ekonomi Kreatif, 2016; Jakarta; Kementerian Koordinator Bidang Perekenomian Republik Indonesia

Admin, (2019, June 3), Masalah Tenaga Kerja dan Angkatan Kerja, https://tugassekolah.co.id/2019/06/masalah-tenaga-kerja-dan-angkatan-kerja.html

Badan Pusat Statistik, (2018), Tenaga Kerja dan Angkatan Kerja, https://www.bps.go.id/subject/6/tenagakerja.html 